\title{
LABOR AND WORKING-CLASS HISTORY AT THE AUSTRALIAN ASSOCIATION OF EUROPEAN HISTORY
}

The biannual Conference of European Historians in Australia was held June 3-5, 1977, in Adelaide, South Australia. The conference was attended by delegates from almost all of the seventeen Australian universities and a number of tertiary colleges. Twelve of the twenty-six papers presented were on labor, working class and affiliated histories, which shows the increasing interest in these fields over recent years.

Robert Stuart (University of Western Australia) opened the conference with a discussion of the Guesdists, members of the parti ouvrier francais which was led by Jules Guesde. Stuart pointed out that although the POF was a relatively minor force in French politics, it was a major factor in the growth of Marxism in France and was to some extent a progenitor of today's parti socialiste francais and parti communiste francais. Stuart questioned the conventional criticism of the POF, made by Claude Willard among others, which points to the simplistic, highly schematic Marxism of the party as a basic weakness. Proponents of this line maintain that if only the Guesdists had been more sophisticated in their Marxism, the POF would have been more successful both in dominating the fragmented French socialist movement and in imposing itself upon France as a whole.

Stuart agreed that the POF made little or no effort to link its dogmatic convictions with a genuine investigation of French society, indeed he maintained that the indictment of the POF for its failure to analyze the real character of French society actually underrates the case. The Guesdists' rigorously bipolar image of French society had no relation ot reality. There was neither a homogeneous and virtually omnipotent haute bourgeoisie nor a proletariat made up of a vast undifferéntiated mass of unskilled factory workers who formed the "vanguard" of the French people. Even less did the Guesdists' concept of bipolar concentration hold for the agricultural population and the petite bourgeoisie. But Stuart disagreed with the assertion that the party's lack of sociological perception was part of its debilitating ideological insufficiency and an obstacle to its success. On the contrary, Stuart believed that the Guesdists' refusal to confront the actuality of their own society was one of the party's major strengths in its struggle to implant "collectivism" in France. To Stuart it was only through the creation and constant reiteration of their myth that the Guesdists were able to sustain their own Marxist convictions and to maintain their followers' faith in the inevitable proletarian revolution. In effect, genuine sociological inquiry would have rendered French Marxism nonsensical at that stage.

If this view is correct, it raises the question of how the POF remained a viable movement at all, given the astonishing unreality of this view. Stuart suggested some tentative answers. He referred to the fact that major elements of the French population were themselves convinced that the development of their society was leading to proletarianization and polarization-although, of course, these notions were not as dear to the French petite and haute bourgeoisie as they were to the Guesdists. Stuart also referred to the importance of the revolutionary tradition in French society and to the fact that at least in some places, e.g., in the textile town of Roubaix, the myth was in fact hard truth. Finally, Stuart suggested that to the French working class, which in the last quarter of the nineteenth century was confronted with continuous humiliation and defeat, the fantasy world of the Guesdists, with its prediction of proletarian victory, may have provided some spiritual comfort. 
For the POF, Stuart concluded, social illusion and inevitable revolution necessitated each other, without the party's adherence to both it may well have been impossible for the Guesdists to have planted the seeds of Marxism in France.

There was disagreement about Gerhard Fischer's (University of New South Wales) paper on the interpretations of the Paris Commune by Bakunin, Marx, Engels, and Lenin. Fischer argued that Bakunin's contribution to the debate had remained largely unnoticed, particularly in Communist countries where, he alleged, it is most needed. To Fischer, Bakunin's explanation of the role of the state has proved much more accurate in forseeing actual historical development, from the Bolshevik revolution to the soviets and beyond. This paper met with considerable questioning from the floor. Bruce Kent (Australian National University, Canberra), for example, pointed to Marx's comments that the Commune was premature for the time, a sneak preview of what the proletarian state of the future would be like. Graham Warrel (Monash University, Melbourne) referred to substantial criticism of the Commune by Trotsky.

Modern Soviet history was well presented at the conference. T.H. Rigby (Australian National University) gave a short summary of his forthcoming book on Soviet Russia's governmental institutions. Rigby analyzed the workings and functioning of the Council of People's Commissars (Sovnarkom) from the seizure of power until its decline in importance in the early 1920s. Rigby suggested that to judge from his substantial research work, qualification is needed of the common assumptions that there was a logical and an historical continuity between the "vanguard" roles of the party before and after the revolution, and that the state was intended from the outset as a junior arm of the "proletarian dictatorship."

- Marian Sawer (University of Adelaide) suggested that the tension existing between Lenin's writings of 1917 (especially State and Revolution) and the organizational beliefs he expressed before and after this period arose from a personal reappraisal of Marxist theory (a reappraisal which preceded the February Revolution) rather than from a purely tactical grasp of the revolutionary possibilities brought about by the collapse of tsarist Russia. State and Revolution, Sawer argued, was the product of both a determinate political conjuncture and a determinate theoretical conjuncture. Before 1917, Lenin only discarded the Kautskian understanding of the state with great reluctance. Sawer showed how the content of the blue note book (published in Leninskii Sbornik, XIV) illustrates Lenin's temporary conversion to Bukharin's position and his short lived rapprochement with left Marxism. Jennifer Crew (University of New England, Armidale, NSW) summarized the recent historiographical controversy about collectivization in the Soviet Union, and Lewis $H$. Siegelbaum (La Trobe University, Melbourne) talked about the Russian industrialists. This "once forgotten class" has been given increasing attention in recent times and has now taken its place beside the peasants, the intelligentsia, and the tsarist government itself as a topic of research into the social and political fabric of Russia before 1917 and the dynamics of the 1917 revolution. Siegelbaum's paper concentrated in particular on the functioning of Russia's war economy.

Konrad Kwiet (University of New South Wales), in his "Notes on the Resistance of German Jews against the Nazis" referred to the particularly vulnerable position of Social Democrats, trade unionists, and Communists of Jewish origin in the anti-fascist resistance movement; they faced death because of both their racial background and their political beliefs. Kwiet pointed to the most famous Jewish resistance group, the Herbert Baum Group, which became hopelessly isolated not 
only from the population, but also within the Communist underground movement. In fact the Communist Party, after the great waves of liquidation and arrest in the mid-thirties, ordered its decimated cadres, "for their own safety "sake," to remove Communists of Jewish origin from their ranks.

John Moses (University of Queensland, Brisbane) in his brief evaluation of the role of the trade unions during the Weimar Republic argued that basically the Free Trade Unions continued their healthy policies of the pre-war and war years which culminated in the formation of the Zentralarbeitsgemeinschaft in 1918. Moses discussed the Unions' program for "economic democracy" which emerged during the 1920s as the goal of German trade unionsim. This goal was not achieved first because the electorate never rewarded the Social Democrats and their trade-union supporters by giving them an absolute majority in the Reichstag, and second because of the crisisridden German economy for which the politicians could find no solution, a failure which was fully exploited by the opponents of the unions and social democracy. It was the tragic fate of the German Free Trade Unions that their naive faith in the constitution of Weimar reaped its reward with their total destruction at the hands of the SS on 2 May 1933. Comments from the floor questioned the viability of the concept of "economic democracy" by pointing to the fact that "co-determination in industry" also failed to materialize more recently when under the Brandt and Schmidt governments the overall circumstances were much more favorable than in the 1920s. It was also commented that the structure of the trade unions - top heavy, age ridden, and strongly bureaucratized thwarted the chance of effective opposition to the much more virile enemies from the political right.

Germany was further dealt with in papers on the recent controversy about the German November Revolution: Derek Bland (Australian National University) assessed the Anglo-Saxon historians and Jürgen Tampke (University of New South Wales) talked about recent German writings under the topic "Was there a third way?"

The conference concluded by thanking the organizers, especially Fred Zuckermann, Heinz Kent, and Decie Denholm, for their efforts. John Moses was elected as the new president of the AAEH, and it was decided that the next meeting will be held at the University of Queensland, Brisbane in 1979.

\section{Jürgen Tampke}

University of New South Wales

Some of the papers presented at the Australian Association of European History:

Robert Stuart, Department of History, University of Western Australia

"French Marxism and its Perception of French Society 1879-1905"

Konrad Kwiet, School of German, University of New South Wales

"Notes on the resistance of German Jews against the Nazis"

Norrie Neumark, Department of Humanities and Social Science, The New South Wales Institute of Technology. "Superior but Equal: The Consciousness of Women in the Russian Intelligentsia"

Bernard Huppauf, School of German, University of New South Wales

"The Relationship between History of Literature and Social History" 
Gerhard Fischer, School of German, University of New South Wales

“ ‘ . . the state begins to wither away ... '; Notes on the Interpretation of the Paris Commune by Bakunin, Marx and Lenin."

Jürgen Tampke, School of History, University of New South Wales

"The German November Revolution and the Third Way"

D.C. Band, Department of Political Science, Australian National University

"The German Revolution of 1918 and the Historians"

T.H. Rigby, Department of Political Science, Australian National University

"The Soviet Government under Lenin"

Lewis Siegelbaum, Department of History, La Trobe University

"Rediscovering Russian Industrialists: The Case for a National Bourgeoisie"

John Moses, Department of History, University of Queensland

"The Concept of Economic Democracy within the German Socialist Trade Unions during the Weimar Republic:

The Emergence of an Alternative Route to Socialism"

Jennifer Crew, Department of History, University of New England,

"Collectivization in the Soviet Union. Did it Work?"

Marian Sawer, Department of Politics, University of Adelaide,

"The Genesis of State and Revolution" 